\title{
GRAIN YIELD OF COFFEE PLANTS FERTILIZED WITH DIFFERENT DOSES OF 20-00-20 NPK FORMULATION UNDER RAINFED CONDITIONS ${ }^{1}$
}

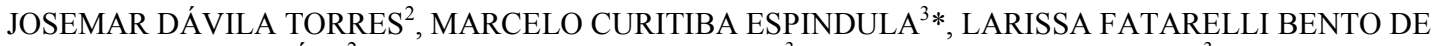 \\ ARAÚJO $^{2}$, ALAERTO LUIZ MARCOLAN $^{3}$, RODRIGO BARROS ROCHA ${ }^{3}$
}

\begin{abstract}
Little is known about the management of high-yield clonal Coffea canephora in the Amazonian Region, mainly for nutritional aspects and cultivation system efficiency. This study aimed to evaluate the influence of different nitrogen and potassium fertilization rates on coffee grain yield and fertilizer use efficiency of $C$. canephora trees. An experiment was performed at an experimental field of the Embrapa Rondônia in Porto Velho (RO), Brazil. It was carried out in a split-plot scheme with six doses of 20-00-20 NPK formulation $\left(0 ; 250 ; 500 ; 1,000 ; 2,000 ;\right.$ and $\left.3,000 \mathrm{~kg} \mathrm{ha}^{-1}\right)$ and three years of evaluation $(2014,2015$, and 2016). An interaction between fertilizer dose and crop year was observed. Fertilizer doses showed an exponential behavior, with maximum yields of 51,114, and $79 \mathrm{bags} \mathrm{ha}^{-1}$ at 3,000 kg ha $\mathrm{ha}^{-1}$ in the crop years of 2014, 2015, and 2016, respectively. Such a behavior impacted average and accumulated yields in the three harvest seasons. As for crop year effect within each fertilizer dose, the highest yield was reached in the second harvest after pruning for renewal of orthotropic stems. Moreover, fertilizer use efficiency by plants decreased exponentially, with the highest value at the lowest dose. Increasing doses of 20-00-20 formulation promoted an exponential increase in grain yield but decreased its use efficiency by $C$. canephora plants. This management also stimulated a strong biannual production.
\end{abstract}

Keywords: Coffea canephora. Nitrogen. Potassium. Fertilizer use efficiency.

\section{PRODUTIVIDADE DE CAFEEIROS FERTILIZADOS COM DOSES DO FORMULADO 20-00-20 EM CONDIÇÕES DE SEQUEIRO}

RESUMO - Informações sobre o manejo do cafeeiro clonais de Coffea canephora de alto rendimento agronômico na Amazônia, ainda são escassas, especialmente no que se refere ao aspecto nutricional e a quantificação da eficiência do sistema de cultivo. Assim, o objetivo neste estudo foi avaliar a influência de doses de adubação nitrogenada e potássica sobre a eficiência do uso de fertilizantes e a produtividade em cafeeiros C. canephora. O experimento foi conduzido no campo experimental da EMBRAPA Rondônia em Porto Velho - RO, em esquema de parcelas subdivididas no tempo, composto pela combinação de 6 doses de fertilizantes $\left(0 ; 250 ; 500 ; 1.000 ; 2.000\right.$ e $3.000 \mathrm{~kg} \mathrm{ha}^{-1}$ do formulado 20-00-20) e 3 anos de avaliação (safras 2014, 2015 e 2016). Foi observado interação entre os fatores doses e anos de avaliação. Para efeito de dose dentro de cada safra foi evidenciado comportamento exponencial, com produções máximas de 51, 114 e 79 sacas $\mathrm{ha}^{-1}$ na dose de $3.000 \mathrm{~kg}$ do formulado em todas as safras avaliadas, respectivamente. Este comportamento foi refletido nas produtividades média e acumulada das três safras. Quanto ao efeito de safras dentro de cada dose, a safra do ano de 2015 apresentou maior produtividade. Para a eficiência do uso dos fertilizantes, o comportamento foi exponencial decrescente apresentando maior eficiência na menor dose. O aumento das doses do formulado promove incremento exponencial da produtividade e decréscimo na eficiência do uso de fertilizantes por cafeeiros Coffea canephora, e sob esse manejo ocorre forte bienalidade de produção.

Palavras-Chave: Coffea canephora. Nitrogênio. Potássio. Eficiência do uso de fertilizantes.

\footnotetext{
${ }^{*}$ Corresponding author

${ }^{1}$ Received for publication in 06/02/2020; accepted in 10/26/2020

Paper extracted from the Master's dissertation of the first author.

${ }^{2}$ Graduate Program in Environmental Sciences, Fundação Universidade Federal de Rondônia, Rolim de Moura, RO, Brazil; josemar-torres@hotmail.com - ORCID: 0000-0001-8050-8637, larissafatarelli@gmail.com - ORCID: 0000-0003-4249-024X.

${ }^{3}$ Agroflorestry Research Center of Rondônia, Empresa Brasileira de Pesquisa Agropecuária, Porto Velho, RO, Brazil; marcelo.espindula@embrapa.br - ORCID: 0000-0001-7481-9746, alaerto.marcolan@embrapa.br - ORCID: 0000-0003-1707-8368, rodrigo.rocha@embrapa.br-ORCID: 0000-0001-5275-5315.
} 


\section{INTRODUCTION}

Together with calcium $(\mathrm{Ca})$, nitrogen $(\mathrm{N})$ and potassium $(\mathrm{K})$ are macronutrients accumulated in large amounts in vegetative shoots of Coffea canephora trees (BAZONI et al., 2020). Both are also required in large amounts by coffee plants during reproductive stages, when accumulations may exceed $10 \mathrm{mg}$ per fruit, at the end of its expansion period (DUBBERSTEIN et al., 2016). Therefore, these elements should receive the most attention in nutritional management programs for Conilon coffee production.

Although general knowledge on nutritional requirements indicates that $\mathrm{N}$ and $\mathrm{K}$ are the most demanded by coffee trees, such demands may vary with genotype (PREZOTTI; BRAGANÇA, 2013; PARTELLI et al., 2014; STARLING et al., 2018) and environmental conditions (COVRE et al., 2016).

Regarding genotype influence, studies have shown that varieties of $C$. canephora or populations distributed worldwide are genetically distinct (MONTAGNON; CUBRY; LEROY, 2012). Even within the same country, as in Brazil, there is high genetic variability among genotypes grown commercially in different Conilon coffee producing regions (FERRÃO et al., 2013; SOUZA et al., 2013). Thus, nutrient calibration studies for this crop should consider agronomic traits of genotypes grown in each region.

As for environmental conditions, factors such as water availability (DAMATTA et al., 2018) and sub- or supra-optimal temperatures (RODRIGUES et al., 2018; RAMALHO et al., 2018) may change coffee metabolism and hence agronomic performance. Climatic conditions in the Brazilian Amazon, in particular high temperatures associated with severe droughts from June to September (ALVARES et al., 2013), may influence plant development, limiting growth period to months with the highest rainfall intensities and lowest temperatures (DUBBERSTEIN el al., 2017). Thus, in this region, nutrient supply is restricted from May to October, mainly in rainfed crops.

To deal with climate and peculiarities of the Amazon region, the Brazilian Agricultural Research Corporation (Embrapa) has developed a clonal variety of Conilon coffee, known as 'BRS Ouro Preto'. It is adapted to cultivation conditions in the Brazilian Southwestern Amazon (RAMALHO et al., 2014). However, little is known about its responses to fertilizers throughout its growth cycle.

In this sense, this study aimed to evaluate the influence of different nitrogen and potassium fertilization rates on yield and fertilizer use efficiency of $C$. canephora plants variety 'BRS Ouro Preto' under rainfed conditions in the Western Amazon.

\section{MATERIAL AND METHODS}

The experiment was carried out at an experimental field of the Embrapa Rondônia, in the city of Porto Velho (RO) Brazil (8 53 '20" S and $\left.63^{\circ} 06^{\prime} 40^{\prime \prime} \mathrm{W}\right)$. It was performed from September 2012 to August 2016. According to Köppen, the local climate is classified as $A m$ type, which stands for rainy tropical with rainy summers (October to May) and dry winters (June to September). Average temperatures range from $26.3{ }^{\circ} \mathrm{C}$ in the summer to $25.9{ }^{\circ} \mathrm{C}$ in the winter. Average annual rainfall is 2,200 mm (ALVARES et al., 2013). Data on rainfall, temperature, and air relative humidity during the experimental period were obtained from a weather station of the Rondônia State Secretariat of Environmental Development (SEDAM, 2020) (Figure 1).

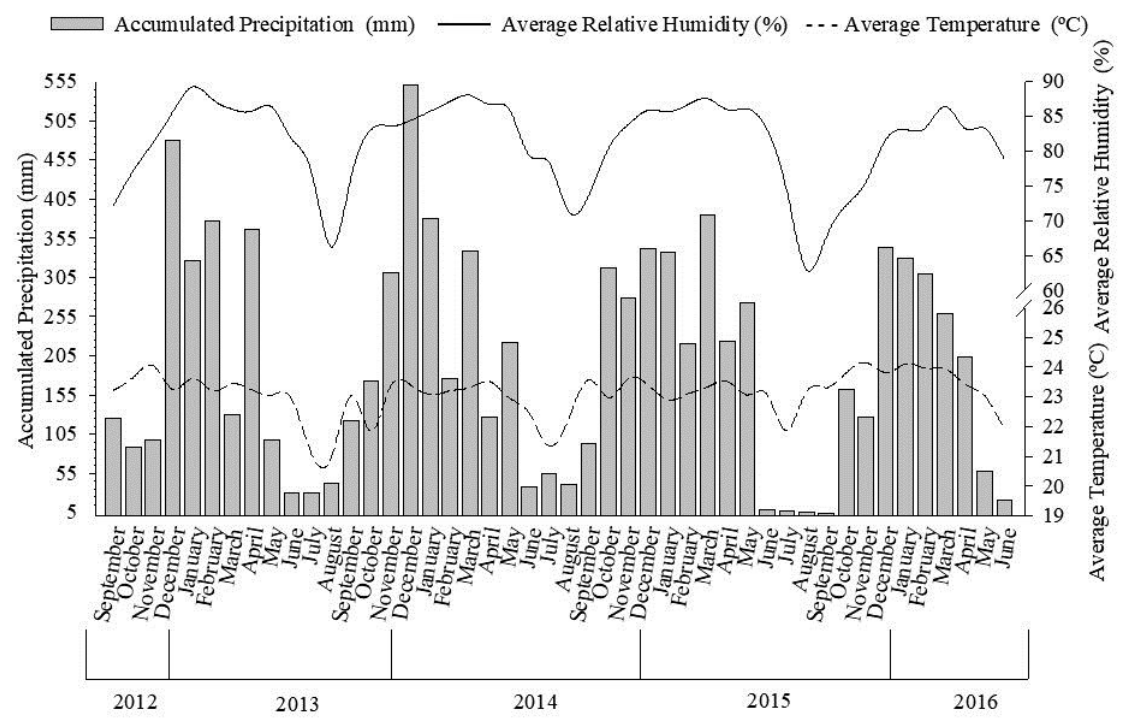

Figure 1. Averages of accumulated rainfall (mm), air relative humidity $(\%)$, and temperature $\left({ }^{\circ} \mathrm{C}\right)$ for the years 2012,2013 , 2014, 2015, and 2016. Source: SEDAM (2020). Porto Velho - RO, Brazil. 
Coffea canephora plants of the clonal variety 'Conilon - BRS Ouro Preto', which is composed of 15 genotypes (clones) of intermediate ripening (May), were grown in the experimental area. These genotypes show typical phenotypic characteristics of plants of the Conilon botanical group. The variety was developed under rainfed conditions (RAMALHO et al., 2014) and has been recommended for cultivation in the Southwestern Amazon.

The coffee trees were implanted in December 2008 and were fertilized to produce 70 bags per hectare during the 2009, 2010, 2011 and 2012 crop years, as recommended by MARCOLAN et al. (2009). In September 2012, their orthotropic branches were drastically pruned to standardize canopy size. After pruning, only 6 branches were maintained per plant $(10,000$ stems per hectare, $3 \times$ $2 \mathrm{~m}$ spacing). Before experiment installation, from
September 2012 to May 2013, plants received $50 \mathrm{~kg} \mathrm{P}_{2} \mathrm{O}_{5}$ (as triple superphosphate), $50 \mathrm{~kg}$ urea nitrogen, $100 \mathrm{~kg}$ ammonium sulfate, $60 \mathrm{~kg} \mathrm{~K} \mathrm{~K}_{2} \mathrm{O}$ (as potassium chloride), and $30 \mathrm{~kg}$ FTE BR-12 fertilizer per hectare. Other treatments were carried out following the technical recommendations for the growing of this crop in the region (MARCOLAN et al., 2015).

The soil of the area was classified as RedYellow Latosol (Oxisol) with clayey texture (SANTOS et al., 2018), and its chemical and physical properties were determined for the depth layers of $0-10,10-20$, and 20-40 cm in July 2013 (Table 1). Before treatment, in August 2013, four tons of dolomitic limestone (with 76\% PRNT) per hectare were applied onto the soil surface, without incorporation. In September 2014, two more tons were applied onto the surface, also without incorporation.

Table 1. Chemical and physical properties at the 0-10, 10-20 and 20-40 cm depth layers of the Red-Yellow Latosol in the Embrapa Rondônia experimental station, Porto Velho - RO, Brazil.

\begin{tabular}{|c|c|c|c|c|c|c|c|c|c|c|c|}
\hline $\begin{array}{l}\text { Depth layer } \\
\text { (cm) }\end{array}$ & $\mathrm{pH}$ & $\mathrm{P}$ & K & $\mathrm{Ca}$ & $\mathrm{Mg}$ & $\mathrm{Al}+\mathrm{H}$ & $\mathrm{Al}$ & CEC & $\mathrm{OM}$ & $\mathrm{m}$ & $\mathrm{V}$ \\
\hline & $\mathrm{H}_{2} \mathrm{O}$ & \multicolumn{2}{|l|}{$\mathrm{mg} \mathrm{dm}{ }^{-3}$} & \multicolumn{5}{|c|}{$\mathrm{cmol}_{\mathrm{c}} \mathrm{dm}^{-3}$} & $\mathrm{~g} \mathrm{~kg}^{-1}$ & \multicolumn{2}{|c|}{------\%--- } \\
\hline $0-10$ & 5.6 & 9,73 & 0,77 & 2,6 & 1,98 & 11,75 & 1,01 & 17,19 & 58,8 & 16 & 29 \\
\hline $10-20$ & 5.4 & 3.11 & 0.38 & 1.64 & 1.31 & 11.89 & 1.32 & 15.22 & 53.2 & 29 & 20 \\
\hline $20-40$ & 5.4 & 4.97 & 0.35 & 1.38 & 1.10 & 11.57 & 0.96 & 14.40 & 45.6 & 26 & 20 \\
\hline \multicolumn{3}{|c|}{ Density } & \multicolumn{4}{|c|}{ Porosity } & \multicolumn{5}{|c|}{ Water content $\left(\mathrm{m}^{3} \mathrm{~m}^{-3}\right)$} \\
\hline Soil (apparent & & & Micro & Mac & & Total & 6 & 10 & $30^{2}$ & 100 & $1,500^{3}$ \\
\hline \multicolumn{3}{|c|}{--------g cm³--------- } & \multicolumn{4}{|c|}{ - } & \multicolumn{5}{|c|}{ 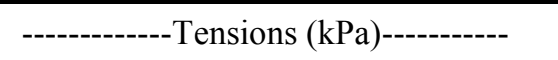 } \\
\hline 1.03 & & & 0.42 & 0.0 & & 0.50 & .42 & 0.41 & 0.37 & 0.34 & 0.27 \\
\hline
\end{tabular}

$\mathrm{pH}$ in water (1: 2.5); O.M. by wet digestion; $\mathrm{P}$ and $\mathrm{K}$ by the Mehlich I method; exchangeable $\mathrm{Ca}, \mathrm{Mg}$, and $\mathrm{Al}$ using $1 \mathrm{~mol} \mathrm{KCl}$.

The experiment was conducted in a split-plot scheme, combining 6 fertilizer doses and three years of evaluation. The main plots consisted of six doses of the NPK formulation 20-00-20 as production fertilization $(0 ; 250 ; 500 ; 1,000 ; 2,000 ;$ and $\left.3,000 \mathrm{~kg} \mathrm{ha}{ }^{-1}\right)$. The subplots comprised the evaluation years of 2014, 2015, and 2016, which are equivalent to the first, second, and third harvest seasons after pruning of orthotropic stems.

The experimental design was fully randomized with 15 replications. Each repetition was composed of one clone of the variety 'Conilon - BRS Ouro Preto'. Each experimental plot consisted of 10 plants continuously arranged in a planting row, spaced $3 \mathrm{~m}$ between rows and $2 \mathrm{~m}$ between plants, totaling 1,667 plants per ha ${ }^{-1}$. The useful plot was the
8 central plants of each experimental plot.

Fertilizer doses were staggered throughout the rainy season of each year, from October 2013 to March 2016, totaling four fertilization cycles. In each year, doses were divided into four applications (October, December, January, and March). Plants were only rainfed without the use of any supplemental irrigation, and crop treatments followed recommendations for the Amazon region.

Phosphorus was supplied twice a year (in

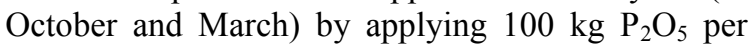
hectare, as simple superphosphate. In October of each year, $50 \mathrm{~kg}$ FTE BR-12 complex fertilizer was applied per hectare for micronutrient supply. In November and March of each year, $20 \mathrm{~kg}$ zinc sulfate, $15 \mathrm{~kg}$ boric acid, and $20 \mathrm{~kg}$ magnesium 
sulfate were also applied.

All plants within the useful area were harvested, and fruits were dried and then benefited for dry grain mass determinations. Based on these, annual, accumulated, and average yields for three years were estimated for the three crop years and expressed in bags per hectare at $12 \%$ humidity.

Fertilizer use efficiency (FUE) for grain production was also evaluated. To this end, we considered the accumulated yield (sum of the three evaluated years) and total amounts of fertilizer applied in the three harvests $(2013 / 14,2014 / 15$, and $2015 / 16)$. The total amounts of fertilizer used were $750 ; 1,500 ; 3,000 ; 6,000$; and 9,000 kg per hectare for the doses of 250;500;1,000;2,000; and 3,000 kg 20-00-20 formulation ha $^{-1}$, respectively. FUE was calculated as the difference between treatment and control yields, then divided by the amount of fertilizer applied to the soil (GOOD; SHRAWAT; MUENCH, 2004), as follows:

FUE $(\mathrm{kg}$ grain per $\mathrm{kg}$ fertilizer $)=\frac{\text { Treatment grain yield }\left(\mathrm{kg} \mathrm{ha}^{-1}\right)-\text { Control grain yield }\left(\mathrm{kg} \mathrm{ha}^{-1}\right)}{\text { Amount of fertilizer applied }\left(\mathrm{kg} \mathrm{h}^{-1}\right)}$

The data were subjected to analysis of variance. Annual averages within each fertilizer dose were compared by the Tukey's test $(\mathrm{p} \leq 0.05)$, using the Genes software (version 2016.6.9) (CRUZ, 2017). Fertilizer dose effects in each year were evaluated by regression analysis, both for average and accumulated yields, as well as for fertilizer use efficiency, using the SigmaPlot ${ }^{\circledR}$ software version 10 (SYSTAT SOFTWARE Inc, 2006).

\section{RESULTS AND DISCUSSION}

Fertilizer doses and evaluation years showed a significant interaction. Dose effects within years had an increasing exponential trend. This indicates that lower doses of 20-00-20 formulation had a more pronounced effect on yield than did the higher ones, tending to stabilize at doses above $2,000 \mathrm{~kg} \mathrm{ha}^{-1}$ (Figure 2). For instance, by using the equation for 2015 , a $2,000 \mathrm{~kg}$ application would yield 103.86 bags $\mathrm{ha}^{-1}$, whereas $3,000 \mathrm{~kg}$ would produce 111.74 bags ha ${ }^{-1}$, that is, around 7.8 extra bags ha ${ }^{-1}$ by adding $1,000 \mathrm{~kg}$ fertilizer. Yet, if a 4,000 kg dose is used, the estimated yield would reach 115.28 bags $\mathrm{ha}^{-1}$.

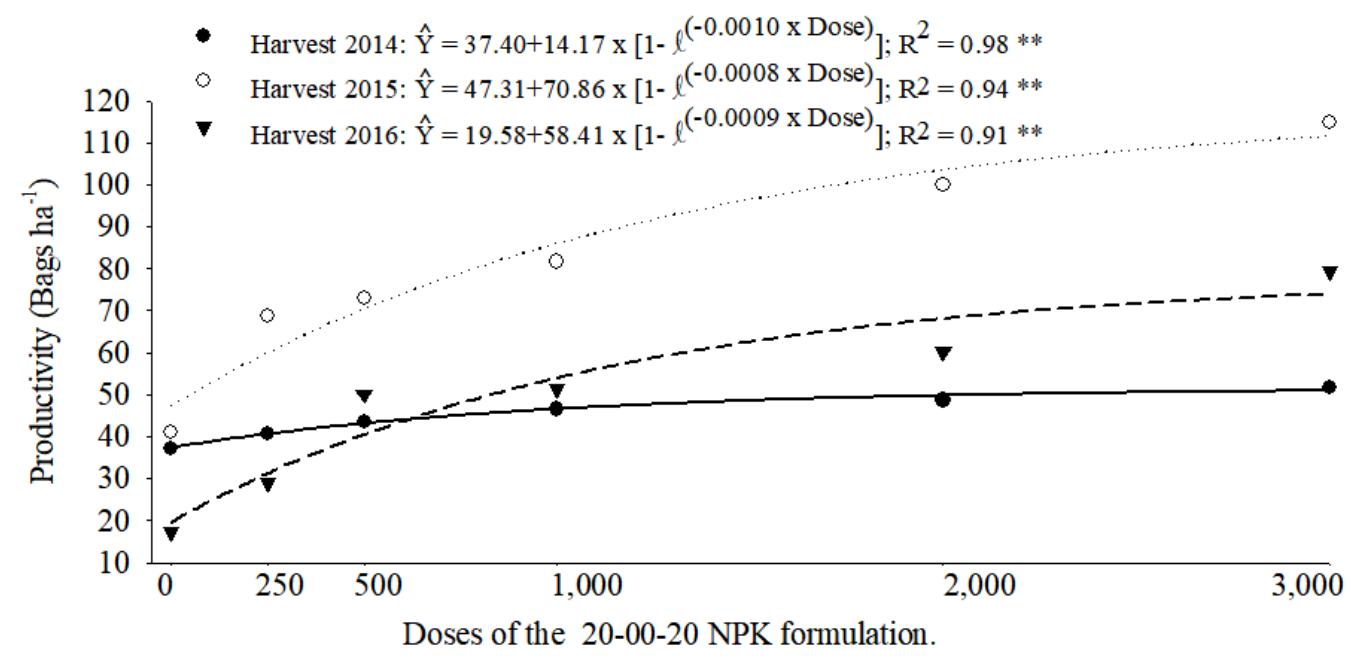

Figure 2. Yield of Coffea canephora 'Conilon - BRS Ouro Preto' coffee trees fertilized with six different doses of the 2000-20 formulation in three harvests $(2014,2015$, and 2016), after pruning of orthotropic stems.

The exponential behavior observed in the three harvests promoted an increase in both average and accumulated yields. Accumulated yields ranged from 104 bags at zero dose to 237 bags at $3,000 \mathrm{~kg}$ fertilizer, while average yield ranged from 34 to 79 bags ha $^{-1}$, respectively (Figure 3 ).

Grain yield exponential behavior in the three harvests, as well as average and accumulated yields (Figures 2 and 3), may be related to biological limitations and agronomic traits of this Conilon variety. Such factors influence plant response to high fertilizer doses.

Biological limitations are related to the genetic potential of the 'Conilon - BRS Ouro Preto' variety, as it is composed of 15 genotypes with different morphological characteristics and productive potentials (RAMALHO et al., 2014). Such diversity ensures improved production stability under several Amazonian conditions but also limits plant responses to fertilizers. This is because genotypes more efficient under nutritional stress may not respond well to fertilization. 


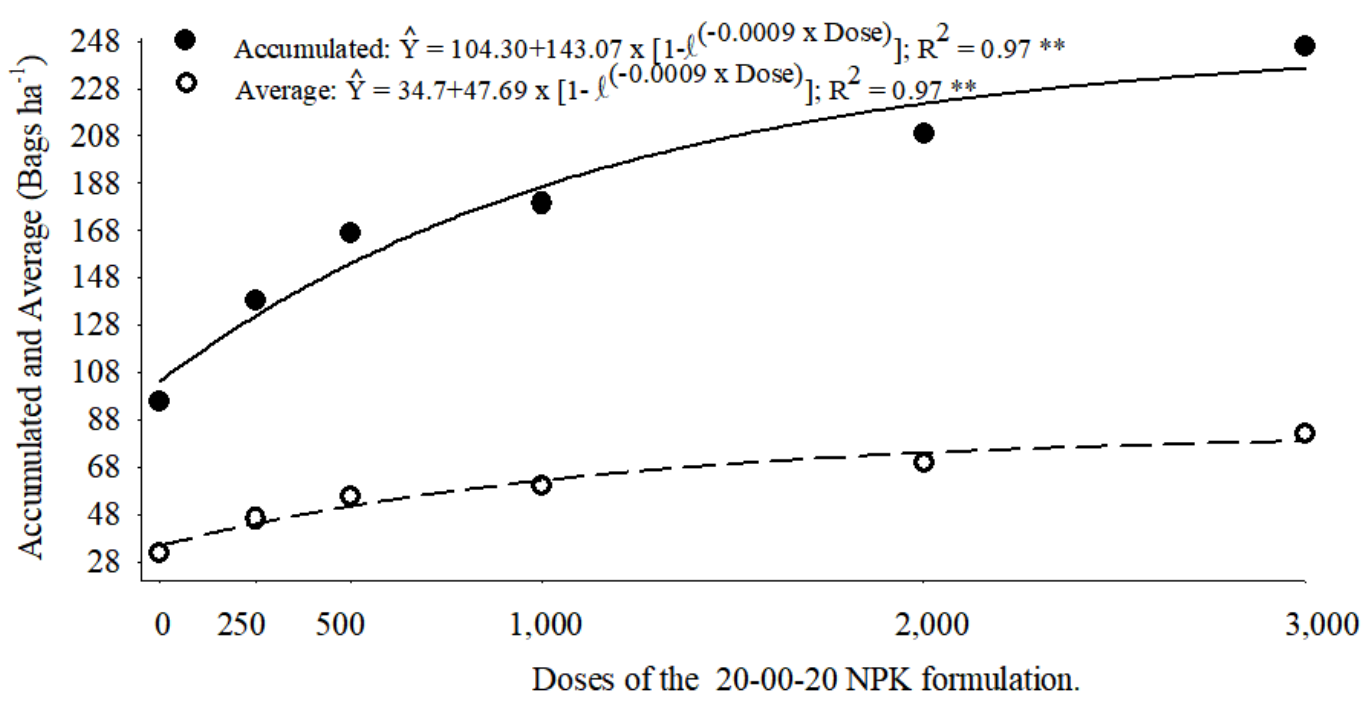

Figure 3. Average and accumulated yields for three crop seasons (2014, 2015, and 2016) of Coffea canephora 'Conilon BRS Ouro Preto' plants fertilized with six different doses of the 20-00-20 formulation.

Agronomic limitations are mainly related to planting density and rainfed systems. In commercial Conilon coffee crops, planting density is about 3,300 plants per hectare, associated with 3 to 4 stems per plant, which increases yield per area (VERDIN FILHO et al., 2014; SAKAI et al., 2015; SILVEIRA et al., 2018) when compared to old practices $(1,600$ plants per hectare and about six stems per plant). This is because plant expansion influences root system distribution, promoting elongation of the main roots and increasing plant efficiency in nutrient and water uptake from the soil. If associated with a programmed pruning, this plant growth per area may reduce self-overgrowth and hence metabolic wear (VERDIN FILHO et al., 2016; SILVA et al., 2019).

As for harvest season effects within each dose, grain yield in 2015 was higher than in 2014 and 2016 for all tested doses but the control (zero dose), for which no difference was seen between 2014 and 2015, which were in turn higher than 2016 (Table 2). For the doses of 250; 500; 1,000; and

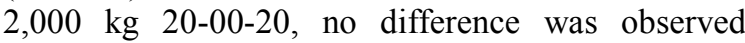
between the first and last production in 2014 and 2016 harvests. However, for the highest dose $\left(3,000 \mathrm{~kg} \mathrm{ha}^{-1}\right)$, production in 2016 was higher than in 2014 (Table 2).

Table 2. Grain yield of Coffea canephora trees, variety 'Conilon - BRS Ouro Preto', fertilized with six doses of the 20-0020 formulation in three harvests after orthotropic stem renewal pruning.

\begin{tabular}{ccccccc}
\hline Year & \multicolumn{5}{c}{ Dose of 20-00-20 formulation $\left(\mathrm{kg} \mathrm{ha}^{-1}\right.$ year-1 $)$} \\
\hline 2014 & 00 & 250 & 500 & 1,000 & 2,000 & 3,000 \\
2015 & $37.11 \mathrm{a}^{*}$ & $40.78 \mathrm{~b}$ & $43.58 \mathrm{~b}$ & $46.57 \mathrm{~b}$ & $48.71 \mathrm{~b}$ & $51.68 \mathrm{c}$ \\
2016 & $40.98 \mathrm{a}$ & $68.76 \mathrm{a}$ & $72.86 \mathrm{a}$ & $81.65 \mathrm{a}$ & $99.84 \mathrm{a}$ & $114.92 \mathrm{a}$ \\
\hline Average & $17.37 \mathrm{~b}$ & $28.86 \mathrm{~b}$ & $50.15 \mathrm{~b}$ & $51.25 \mathrm{~b}$ & $60.38 \mathrm{~b}$ & $79.39 \mathrm{~b}$ \\
\hline CV (\%) & 31.86 & 46.13 & 58.86 & 59.82 & 69.64 & 81.99 \\
\hline
\end{tabular}

*Means followed by the same letter in the column does not differ from each other by the Tukey's test at $5 \%$ significance.

Low yield in the first year of evaluation is related to vegetative limitations after drastic pruning (Table 2). This is because orthotropic stems and plagiotropic branches were only 10 months old to develop until subsequent flowering (from September
2012 to July 2013). In other words, short growth time associated with a slow initial growth after drastic pruning reduced numbers of nodes (rosettes) with productive buds. In this sense, when treatments began in October 2013, productive potential in the 
2014 harvest had already been defined by the flowering in July and August. Thus, yield increase due to a rise in the amount of fertilizer may be related to grain expansion and not to an increase in the number of produced grains.

Yield levels and their increases due to fertilizer doses in the second crop year, 2015 (Table 2 ), are related to effects of fertilizer added in the $2013 / 2014$ harvest on the $2014 / 2015$ cycle. As the number of fruits was limited in the previous harvest (2014), $\mathrm{N}$ and $\mathrm{K}$ were reallocated to vegetative parts of plants, increasing their vegetative growth and hence production potential in the subsequent crop year (2015). These results confirm biennial bearing, which is a common phenomenon in plants of the genus Coffea (VALADARES et al., 2013; PINTO et al., 2014). Conversely, this biennial behavior promoted a reduction in yield in the subsequent harvest of 2016 (Table 2). Accordingly, since there was a high fruit production in the 2015 harvest, these drained resources and reduced vegetative growth, which compromised the 2016 harvest.

Fertilizer use efficiency (FUE) decreased exponentially with increasing fertilizer doses. It decreased from $3.4 \mathrm{~kg}$ grains $\mathrm{kg}^{-1}$ fertilizer at the dose of $750 \mathrm{~kg}$ to $1.0 \mathrm{~kg} \mathrm{~kg}^{-1}$ at the dose of $9,000 \mathrm{~kg}$ of the formulation (Figure 4).

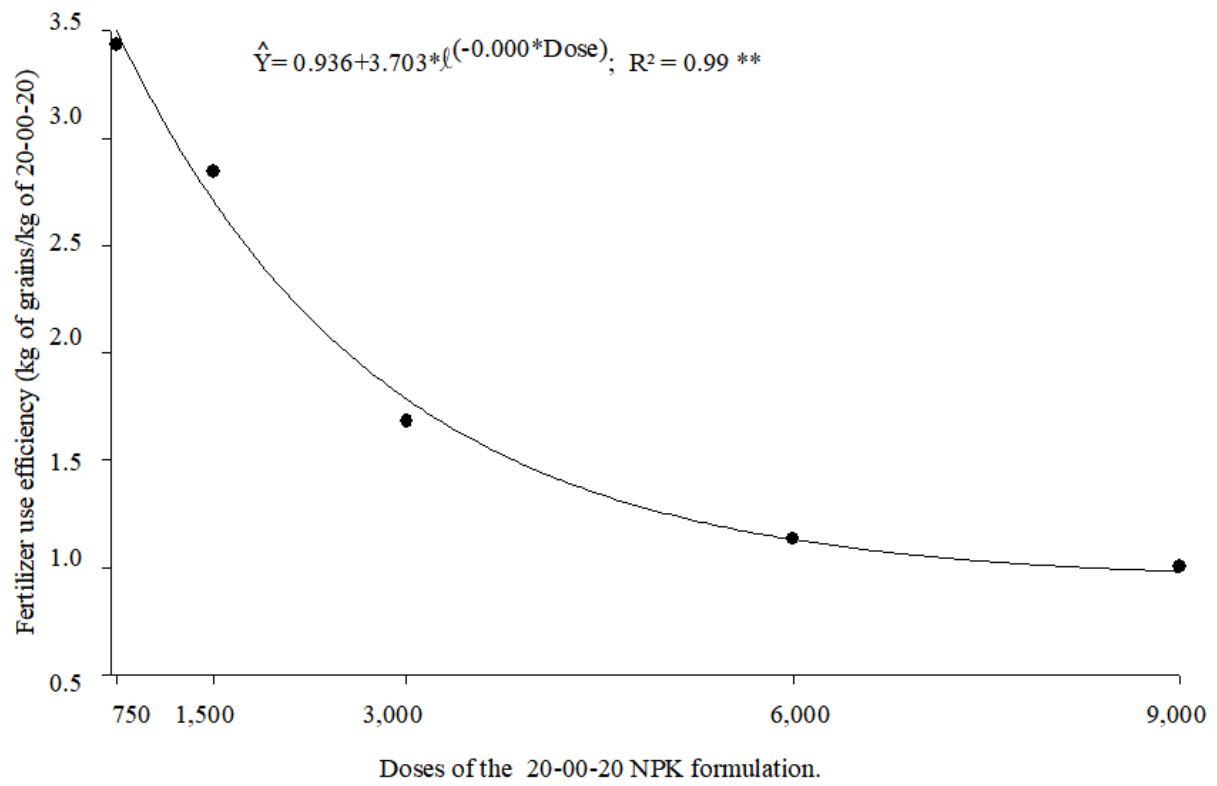

Figure 4. Fertilizer use efficiency (FUE, in $\mathrm{kg}$ of grains per $\mathrm{kg}$ of 20-00-20) in Coffea canephora plants of the variety 'Conilon - BRS Ouro Preto' fertilized with six doses of the 20-00-20 formulation.

The decreasing exponential behavior of FUE (Figure 4) seems to be related to the residual effect of nutrients in the soil (Table 1). This may have ensured fruit yield at low or even at zero fertilizer doses. Moreover, FUE decrease with increasing fertilizer doses indicates that plants did not metabolize all the applied nutrients. Part of the nutrients was lost due to leaching to subsurface layers, runoff, or even ammonia volatilization (ESPINDULA et al., 2021). Whereas the other portion may have been immobilized in plant litter on the soil surface (REICHARDT et al., 2009).

\section{CONCLUSIONS}

In Western Amazon under rainfed conditions, Coffea canephora trees of the variety 'Conilon BRS Ouro Preto' respond exponentially to an increase in doses of the 20-00-20 formulation, showing significant increases up to the dose of $2,000 \mathrm{~kg} \mathrm{ha}{ }^{1}$. The coffee plants also show a seasonal behavior, with maximum yields in the second crop year after drastic pruning for orthotropic stem renewal. Fertilizer use efficiency by this Conilon variety under rainfed conditions decreases exponentially with increasing doses of the 20-00-20 formulation.

\section{ACKNOWLEDGEMENTS}

The authors want to thank the Brazilian Consortium for Coffee Research and Development for the financial support to this research (Project Code: 02.13.02.046.00.04.00) and to the Coordenação de Aperfeiçoamento de Pessoal de Nivel Superior (CAPES) for the scholarships granted to the first and third authors. 


\section{REFERENCES}

ALVARES, C. A. et al. Köppen's climate classification map for Brazil. Meteorologische Zeitschrift, 22: 711-728, 2013.

BAZONI, P. A. et al. Production of cuttings and nutrient export by Coffea canephora in different periods in the Southwestern Amazon. Revista Brasileira de Engenharia Agrícola e Ambiental, 24: 162-169, 2020.

COVRE, A. M. et al. Nutrient accumulation in bean and fruit from irrigated and non-irrigated Coffea canephora cv. Conilon. Emirates Journal of Food and Agriculture, 28: 402-409, 2016.

CRUZ, C. D. Programa Genes: Versão 2016.6.9. 2017. Disponível em: <http://arquivo.ufv.br/dbg/ genes/genes.htm>. Acesso em: 24 out. 2019.

DAMATTA, F. M. et al. Physiological and agronomic performance of the coffee crop in the context of climate change and global warming: a review. Journal of Agricultural and Food Chemistry, 66: 5264-5274, 2018.

DUBBERSTEIN, D. et al. Concentration and accumulation of macronutrients in leaf of coffee berries in the Amazon, Brazil. Australian Journal of Crop Science, 10: 701 - 710, 2016.

DUBBERSTEIN, D. et al. Influência da adubação no crescimento vegetativo de cafeeiros na Amazônia Sul Ocidental. Coffee Science, 12: 197-206, 2017.

ESPINDULA, M. C. et al. Ammonia loss from protected urea in soil under different irrigation depths. Acta Scientiarum.Agronomy, v. 43, e46764, 2021.

FERRÃO, L. F. V. et al. Comparative study of different molecular markers for classifying and establishing genetic relationships in Coffea canephora. Plant Systematics and Evolution, 299: 225-238, 2013.

GOOD, A. G.; SHRAWAT, A. K.; MUENCH, D. G. Can less yield more? Is reducing nutrient input into the environment compatible with maintaining crop production? Trends in Plant Science, 9: 597-605, 2004.

MARCOLAN, A. L. et al. Cultivo dos Cafeeiros Conilon e Robusta para Rondônia. 3. ed. Porto Velho, RO: Embrapa Rondônia, 2009. 72 p. (Sistemas de Produção, 33).

MARCOLAN, A. L. et al. Manejo Nutricional. In:
MARCOLAN, A. L.; ESPINDULA, M.C. (Eds). Café na Amazônia. Porto Velho, RO: Embrapa Rondônia, 2015. v. 1, cap. 8, p. 177-193.

MONTAGNON, C.; CUBRY, P.; LEROY, T. Amélioration génétique du caféier Coffea canephora Pierre: connaissances acquises, stratégies et perspectives. Cahiers Agricultures, 21: 143-153, 2012.

PARTELLI, F. L. et al. Dry matter and macronutrient accumulation in fruits of Conilon coffee with different ripening cycles. Revista Brasileira de Ciência do Solo, 38: 214-222, 2014.

PINTO, C. et al. Faixas críticas de teores foliares de macronutrientes primários para cafeeiros fertirrigados no primeiro ano pós-plantio. Coffee Science, 8: 530-538, 2014.

PREZOTTI, L. C.; BRAGANÇA, S. M. Accumulation of dry mass, N, P and $\mathrm{K}$ in different genetic sources of Conilon coffee. Coffee Science, 8: 284-294, 2013

RAMALHO, A. R. et al. Cultivar de cafeeiro Conilon BRS Ouro Preto: características agronômicas e agroindustriais. 1. ed. Porto Velho, RO: Embrapa Rondônia, 2014. 10 p. (Comunicado Técnico, 396).

RAMALHO, J. C. et al. Can Elevated Air $\left[\mathrm{CO}_{2}\right]$ Conditions Mitigate the Predicted Warming Impact on the Quality of Coffee Bean? Frontiers in Plant Science, 9: 287, 2018.

REICHARDT, K. et al. Relação entre a adubação nitrogenada e as condições hídricas do solo para um cafezal de Piracicaba, SP. Coffee Science, 4: 41-55, 2009.

RODRIGUES, W. P. et al. Stomatal and photochemical limitations of photosynthesis in coffee (Coffea spp.) plants subjected to elevated temperatures. Crop and Pasture Science, 69: 317 325,2018

SAKAI, E. et al. Coffee productivity and root systems in cultivation schemes with different population arrangements and with and without drip irrigation. Agricultural Water Management, 148: 16-23, 2015.

SANTOS, H. G. et al. Sistema Brasileiro de Classificação de Solos. 5. ed. Brasília, DF: Embrapa, 2018. 356 p.

SECRETARIA DE DESENVOLVIMENTO AMBIENTAL - SEDAM. Rede de Monitoramento. 
Disponível em: < http://www.coreh.sedam.ro.gov.br/ meteorologia/>. Acesso em: 17 dez. 2020.

SILVA, D. R. et al. Compatibility Test and Agronomic Performance of Coffee Genotypes (Coffea canephora Pierre ex Froehner) in the State of Rondônia, Brazil. Journal of Agricultural Science, 11: 162-170, 2019.

SILVEIRA, J. et al. Densidade populacional de cultivares na produtividade e qualidade de grãos de café arábica. Pesquisa Agropecuária Tropical, 48: 358-363, 2018.

SOUZA, F. F. et al. Molecular diversity in Coffea canephora germplasm conserved and cultivated in Brazil. Crop Breeding and Applied Biotechnology, 13: 221-227, 2013.

STARLING, L. C. T. et al. Variability and nutritional balance among genotypes of Coffea canephora (Rubiaceae) in drought versus adequate water supply. Genetics and Molecular Research, 17: 1-13 2018

SYSTAT SOFTWARE Inc - SSI. Sigma Plot for Windows version 10. 2006. Disponível em: < https://systatsoftware.com/products/sigmaplot/>. Acesso em: 24 ago. de 2018.

VALADARES, S. V. et al. Produtividade e bienalidade da produção de cafezais adensados, sob diferentes doses de N e K. Pesquisa Agropecuária Brasileira, 48, 296-303, 2013.

VERDIN FILHO, A. C. et al. Conilon coffee yield using the programmed pruning cycle and different cultivation densities. Coffee Science, 9: 489-494, 2014.

VERDIN FILHO, A. C. et al New management technology for arabica coffee: the cyclic pruning program for arabica coffee. Coffee Science, 11: 475483, 2016. 